\title{
The IHG index for hydromorphological quality assessment of rivers and streams: updated version
}

\author{
Alfredo Ollero ${ }^{1, *}$, Askoa Ibisate ${ }^{2}$, Laura Elísabet Gonzalo ${ }^{3}$, Vanesa Acín ${ }^{4}$, Daniel Ballarín 5 , \\ Elena Díaz ${ }^{2}$, Sergio Domenech ${ }^{6}$, Marcos Gimeno ${ }^{1}$, David Granado ${ }^{4}$, Jesús Horacio ${ }^{7}$, Daniel \\ Mora $^{5}$ and Miguel Sánchez ${ }^{1}$
}

${ }^{1}$ Section of Physical Geography, Dept. of Geography and Land Management, University of Zaragoza.

${ }^{2}$ Section of Physical Geography, Dept. of Geography, Prehistory and Archaeology, University of the Basque Country.

${ }^{3}$ Section of Physical Geography, Dept. of Environment and Soil Sciences, University of Lleida.

${ }^{4}$ Ecology and Land (Ecoter, S.C.)

${ }^{5}$ Environment, Land and Geography (Mastergeo, S.L.)

${ }^{6}$ UTE Ebro Basin Hydrological Information.

${ }^{7}$ Section of Physical Geography, Dept. of Geography, University of Santiago de Compostela.

* Corresponding author: aollero@unizar.es

Received: 24/2/2010 Accepted: 2/12/2010

\begin{abstract}
The IHG index for hydromorphological quality assessment of rivers and streams: updated version

An updated version of the IHG index is presented. The index is based on three appraisal parameters: 1) the functional quality of the fluvial system, including a) flow regime naturalness, b) sediment supply and mobility, and c) floodplain functionality; 2) the channel quality, including a) channel morphology and planform naturalness, b) riverbed continuity and naturalness of the longitudinal and vertical processes, and c) riverbank naturalness and lateral mobility; and 3) the riparian corridor quality, including a) longitudinal continuity, b) riparian corridor width, and c) structure, naturalness and cross-sectional connectivity.
\end{abstract}

Key words: Fluvial systems, hydrology, fluvial geomorphology, hydromorphological indicators, river assessment.

\section{RESUMEN}

\section{Versión actualizada del índice IHG para la evaluación de la calidad hidromorfológica fluvial}

Se presenta una versión actualizada del índice IHG, que se estructura en tres grupos de parámetros: 1) calidad funcional del sistema fluvial, incluyendo a) naturalidad del régimen de caudal, b) disponibilidad y movilidad de sedimentos y c) funcionalidad de la llanura de inundación; 2) calidad del cauce, incluyendo a) naturalidad del trazado y de la morfología en planta, $b$ ) continuidad y naturalidad del lecho y de los procesos longitudinales y verticales y c) naturalidad de las márgenes y de la movilidad lateral; y 3) calidad de las riberas, incluyendo a) continuidad longitudinal, b) anchura y c) estructura, naturalidad y conectividad transversal.

Palabras clave: Sistemas fluviales, hidrología, geomorfología fluvial, indicadores hidromorfológicos, evaluación fluvial. 


\section{INTRODUCTION}

Hydrogeomorphological river dynamics is the key factor in fluvial systems. It is important not only in functional terms but also in terms of the ecological, landscape and environmental value of the systems (Malavoi and Bravard, 2010). The IHG hydrogeomorphological assessment index is used to implement the 2000/60/EU Directive to reduce the deterioration of fluvial systems, to identify, understand and solve or mitigate the environmental problems of these systems, to improve and conserve their functionality and naturalness, to recognise their hydrogeomorphological values, to train managers and students and to raise awareness in society.

The index was first presented in Barcelona in April 2006 at a workshop on tools for hydromorphological quality assessment in rivers organised by the Water Agency of Catalonia. A first version was published in the journals Geographicalia (Ollero et al., 2007) and Limnetica (Ollero et al., 2008), and a user guide is available on the website of the Ebro Basin Water Authority (Ollero et al., 2009). The IHG index has been applied to more than 400 river and stream reaches (Gonzalo, 2009; Díaz and Ibisate, 2009; Gimeno, 2009; Acín et al., 2009; Ballarín and Mora, 2010). It has also been considered and applied by other research groups: Raven et al. (2010), ÁlvarezCabría et al. (2010), and Rinaldi et al. (2010).

The experiences obtained from these applications have led the authors to propose some methodological changes to the index. These changes include the assessment of more hu- man impacts and the modifications of some scores. The evaluation of riparian corridor quality has also been restructured. In this short communication, we present the updated version of the IHG index in English, integrating all the changes mentioned above.

\section{UPDATED VERSION}

The IHG evaluates nine parameters arranged in three groups: fluvial system functional quality, channel quality and riparian corridor quality. Each parameter has an initial score of 10, corresponding to the natural state and functionality of the system. However, after the impacts and pressures are assessed, points are deducted from this initial value according to different criteria. The full IHG hydrogeomorphological assessment of each river reach is performed by adding the nine values obtained. The highest possible score is 90 points. If the score is between 75 to 90 points, the hydrogeomorphological quality is considered very good. Scores from 60 to 74 points are considered good, scores from 42 to 59 are considered moderate, scores from 21 to 41 points are considered poor and scores from 0 to 20 points are considered very bad. However, the index could also be used to assess the quality of the system based on a single group of parameters: the functionality, the riverbed quality, or the quality of the riparian corridor. In such cases, only the values of the 3 parameters within each of these groups will be added, with a maximum value of 30 points (Table 1). Moreover, before the application of

Table 1. Total and partial scores for each section of the IHG index and hydrogeomorphological quality classes. Puntuación y calidad hidrogeomorfológica final.

\begin{tabular}{|c|l|c|l|c|l|l|l|}
\hline \multicolumn{2}{|c|}{$\begin{array}{c}\text { functional } \\
\text { quality }\end{array}$} & \multicolumn{2}{c|}{$\begin{array}{c}\text { channel } \\
\text { quality }\end{array}$} & \multicolumn{2}{c|}{$\begin{array}{c}\text { total hydrogeomorphological } \\
\text { quality }\end{array}$} \\
\hline $25-30$ & very good & $25-30$ & very good & $25-30$ & very good & $75-90$ & very good \\
\hline $20-24$ & good & $20-24$ & good & $20-24$ & good & $60-74$ & good \\
\hline $14-19$ & moderate & $14-19$ & moderate & $14-19$ & moderate & $42-59$ & moderate \\
\hline $7-13$ & poor & $7-13$ & poor & $7-13$ & poor & $21-41$ & poor \\
\hline $0-6$ & very bad & $0-6$ & very bad & $0-6$ & very bad & $0-20$ & very bad \\
\hline
\end{tabular}


Table 2. Assessment of the functional quality. Valoración de la calidad funcional.

Flow regime naturalness

\begin{tabular}{|l|l|c|}
\hline Water discharge, its temporal distribution and its extreme events respond to natural dynamics; this enables the & \multirow{2}{*}{10} \\
fluvial system to perfectly perform its role as hydrological mean of transport
\end{tabular}

Sediment supply and mobility

The sediment discharge arrives at the functional reach without any retention of human origin and the fluvial system carries out the functions of sediment entrainment and transport without any restrictions

There are dams or

weirs with the

ability to retain

sediments in the

watershed and

further upstream

\begin{tabular}{|c|c|c|c|c|}
\hline \multicolumn{4}{|c|}{ if more than $75 \%$ of the watershed area upstream the reach } & -5 \\
\hline \multicolumn{4}{|c|}{$\begin{array}{l}\text { if between } 50 \% \text { and } 75 \% \text { of the watershed area upstream the reach presents sediment } \\
\text { retention }\end{array}$} & \\
\hline \multicolumn{4}{|c|}{$\begin{array}{l}\text { if between } 25 \% \text { and } 50 \% \text { of the watershed area upstream the reachpresents sediment } \\
\text { retention }\end{array}$} & -3 \\
\hline \multicolumn{4}{|c|}{$\begin{array}{l}\text { if there are dams or weirs that retain sediments, although these effect less than } 25 \% \text { of the } \\
\text { watershed area upstream the reach }\end{array}$} & -2 \\
\hline \multirow{2}{*}{\multicolumn{2}{|c|}{$\begin{array}{l}\text { gravel and/or sand extractions and/or dredging which limit } \\
\text { nobility }\end{array}$}} & remarkabl & $\mathrm{d}$ frequent & -2 \\
\hline & & & 1 \\
\hline \multirow{2}{*}{\multicolumn{3}{|c|}{$\begin{array}{l}\text { symptoms or signs of difficulties in the sediment mobility (armouring, } \\
\text { tions of the specific stream power, growth of certain plants...) which can be } \\
\text { actors }\end{array}$}} & remarkable & -2 \\
\hline & & & minor & -1 \\
\hline \multirow{3}{*}{$\begin{array}{l}\mathrm{k} \text { and the small tributaries that flow into } \\
\text { alterations that affect the sediment } \\
\text { nection with the valley, the floodplain } \\
\text { continuous }\end{array}$} & \multicolumn{3}{|c|}{ very important alterations and/or disconnections } & p \\
\hline & \multicolumn{3}{|c|}{ significant alterations and/or disconnections } & 2 \\
\hline & \multicolumn{3}{|c|}{ minor alterations and/or disconnections } & 1 \\
\hline
\end{tabular}

Floodplain functionality

In the reach there are gravel and/or sand extractions and/or dredging which limi sediment supply and mobility

In the reach there are symptoms or signs of difficulties in the sediment mobility (armouring,

embeddedness, alterations of the specific stream power, growth of certain plants...) which can be attributed to human factors

The drainage network and the small tributaries that flow into the reach have human alterations that affect the sediment mobility or their connection with the valley, the floodplain or the riverbed is not continuous

ctions, its energy dissipation functions in flood processes, dispersal of The floodplain can exert, without human restrictions, its energy
peak flows due to sediment overflow and sediments deposition The floodplain has dikes that restrict the natural functions of peak flow reduction, decantation and energy dissipation

\begin{tabular}{|c|c|c|c|c|c|c|}
\hline \multirow{2}{*}{\multicolumn{2}{|c|}{$\begin{array}{l}\text { loodplain has dikes that restrict the } \\
\text { l functions of peak flow reduction, } \\
\text { tation and energy dissipation } \\
\begin{array}{l}\text { if defences directly attached to the } \\
\text { channel prevail }\end{array}\end{array}$}} & $\begin{array}{c}\text { if the defences are } \\
\text { continuous }\end{array}$ & \multicolumn{2}{|c|}{$\begin{array}{l}\text { if they are not continuous but } \\
\text { exceed } 50 \% \text { of the floodplain } \\
\text { length }\end{array}$} & \multicolumn{2}{|c|}{$\begin{array}{l}\text { if they reach less than } \\
50 \% \text { of the floodplain } \\
\text { length }\end{array}$} \\
\hline & & -5 & & -4 & -3 & \\
\hline \multicolumn{2}{|c|}{$\begin{array}{l}\text { if they are separated from the channel } \\
\text { but restrict more than } 50 \% \text { of the } \\
\text { floodplain width }\end{array}$} & -4 & & -3 & \multicolumn{2}{|l|}{-2} \\
\hline \multicolumn{2}{|c|}{$\begin{array}{l}\text { if there are only far defences that } \\
\text { restrict less than } 50 \% \text { of the } \\
\text { floodplain width }\end{array}$} & -3 & & -2 & \multicolumn{2}{|l|}{-1} \\
\hline \multirow{2}{*}{\multicolumn{4}{|c|}{$\begin{array}{l}\text { odplain has cross section alterations (defences, raised communication } \\
\text { buildings, ditches...) that modify the hydro-geomorphological processes of } \\
\text { pping, flooding and flood flows }\end{array}$}} & \multicolumn{2}{|c|}{ if there are many obstacles } & -2 \\
\hline & & & & \multicolumn{2}{|c|}{ if there are few obstacles } & -1 \\
\hline \multirow{3}{*}{$\begin{array}{l}\text { loodplain presents land } \\
\text { hat reduce its natural } \\
\text { onality or it has been } \\
\text { way from the channel } \\
\text { dredging or } \\
\text { elisation }\end{array}$} & \multicolumn{5}{|c|}{ if the raised land or the land impervious to water exceeds $50 \%$ of the surface } & -3 \\
\hline & \multicolumn{5}{|c|}{$\begin{array}{l}\text { if the raised land or the land impervious to water constitute between } 15 \% \text { and } 50 \% \text { of } \\
\text { its surface }\end{array}$} & -2 \\
\hline & \multicolumn{5}{|c|}{$\begin{array}{l}\text { if there are raised land or land impervious to water, although it constitutes less than } \\
15 \% \text { of its surface }\end{array}$} & -1 \\
\hline
\end{tabular}

The floodplain has cross section alterations (defences, raised communication $\quad$ if there are many obstacles ways, buildings, ditches...) that modify the hydro-geomorphological processes of overtopping, flooding and flood flows

\begin{tabular}{l|l} 
The floodplain presents land & if the raised land or the land impervious to water exceeds $50 \%$ of the surface
\end{tabular} uses that reduce its natural functionality or it has been kept away from the channel due to dredging or channelisation if the raised land or the land impervious to water constitute between $15 \%$ and $50 \%$ of its surface if there are raised land or land impervious to water, although it constitutes less than $15 \%$ of its surface 
Table 3. Assessment of the channel quality. Valoración de la calidad del cauce.

\section{Channel morphology and planform naturalness}

The channel morphology remains natural, unaltered and its morphology in planform presents the features and dimensions coincident with the basin and valley characteristics, as well as with the system's natural behaviour

Artificial morphology changes and direct human modifications of the channel's morphology in planform have been recorded

if they have an
effect on more
than $50 \%$ of the
reach length

if they have an
effect on
between $25 \%$
and $50 \%$ of the
length
if they have an
effect on a

length between $10 \%$ and $25 \%$

\section{if they have an effect on less than $10 \%$ of the reach length}

\begin{tabular}{|l|l|l|l|l|}
$\begin{array}{l}\text { if there are drastic changes } \\
\text { (diversions, cut-offs, fill-in of } \\
\text { abandoned channels, branch } \\
\text { simplification...) }\end{array}$ & -8 & -7 & -6 & -5 \\
\hline $\begin{array}{l}\text { if not drastic changes, minor } \\
\text { changes are indeed recorded } \\
\text { (setting back embankment, } \\
\text { realignment ...) }\end{array}$ & -6 & -5 & -4 & -3 \\
\hline $\begin{array}{l}\text { if not recent drastic or minor } \\
\text { changes, there are old changes that } \\
\text { the fluvial system has recovered } \\
\text { partially }\end{array}$ & -4 & -3 & -2 & -1 \\
\hline
\end{tabular}

morphology due to human activities in the basin or to the effect of infrastructures

Riverbed continuity and naturalness of the longitudinal and vertical processes

The channel is natural and continuous and its hydromorphological longitudinal and vertical processes are functional, natural and coincident with the basin and valley characteristics, the substrate, the slope and the hydrological behaviour

\begin{tabular}{|c|c|c|c|c|c|}
\hline $\begin{array}{l}\text { In the functional reach there are cross section } \\
\text { alterations that break its continuity }\end{array}$ & \multicolumn{2}{|c|}{$\begin{array}{l}\text { if they dam more than } \\
50 \% \text { of the reach } \\
\text { length }\end{array}$} & $\begin{array}{l}\text { if they dam from } 25 \\
\text { to } 50 \% \text { of the reach } \\
\text { length }\end{array}$ & \multicolumn{2}{|c|}{$\begin{array}{l}\text { if they dam less } \\
\text { than } 25 \% \text { of the } \\
\text { reach length }\end{array}$} \\
\hline $\begin{array}{l}\text { if there is at least a dam higher than } 10 \mathrm{~m} \\
\text { and with no bypass for sediments }\end{array}$ & \multicolumn{2}{|l|}{-5} & -4 & \multicolumn{2}{|c|}{-3} \\
\hline $\begin{array}{l}\text { if there are some weirs or at least a dam } \\
\text { higher than } 10 \mathrm{~m} \text { with bypass for sediments }\end{array}$ & \multicolumn{2}{|l|}{-4} & -3 & \multicolumn{2}{|c|}{-2} \\
\hline if there is a single weir & \multicolumn{2}{|l|}{-3} & -2 & \multicolumn{2}{|c|}{-1} \\
\hline \multirow{2}{*}{\multicolumn{2}{|c|}{$\begin{array}{l}\text { There are bridges, fords or other minor obstacles that alter the } \\
\text { longitudinal continuity of the channel }\end{array}$}} & \multicolumn{3}{|c|}{ more than 1 per channel $\mathrm{km}$} & -2 \\
\hline & & \multicolumn{3}{|c|}{ less than 1 per channel $\mathrm{km}$} & -1 \\
\hline \multirow{3}{*}{\multicolumn{2}{|c|}{$\begin{array}{l}\text { The topography of the riverbed, the bedform sequences, the } \\
\text { granulometry-morphometry of the materials or the riverbed aquatic or } \\
\text { pioneer vegetation show symptoms of having been altered by } \\
\text { dredging, extractions, floorings or clearances }\end{array}$}} & \multicolumn{3}{|c|}{ in more than $25 \%$ of the reach length } & -3 \\
\hline & & \multicolumn{3}{|c|}{ in between 5 and $25 \%$ of the reach length } & -2 \\
\hline & & \multicolumn{3}{|c|}{ in odd cases } & -1 \\
\hline
\end{tabular}

\section{Riverbank naturalness and lateral mobility}

The channel is natural and has the ability to move laterally without restrictions, since its natural banks pre-sent a morphology according to its hydrogeomorphological processes of erosion and sedimentation

The channel has undergone a total canalization or there are discontinuous bank defences or infrastructures (buildings, communication ways, ditches ...) next to the banks

\begin{tabular}{|c|c|c|}
\hline \multicolumn{2}{|l|}{ in more than $75 \%$ of the segment length } & -6 \\
\hline \multicolumn{2}{|l|}{ in between $50 \%$ and $75 \%$ of the segment length } & -5 \\
\hline \multicolumn{2}{|l|}{ in between $25 \%$ and $50 \%$ of the segment length } & -4 \\
\hline \multicolumn{2}{|l|}{ in between 10 and $25 \%$ of the segment length } & -3 \\
\hline \multicolumn{2}{|l|}{ in between 5 and $10 \%$ of the segment length } & -2 \\
\hline \multicolumn{2}{|l|}{ in less than $5 \%$ of the segment length } & -1 \\
\hline \multirow[t]{2}{*}{ garbage or interventions that modify their natural } & remarkable & -2 \\
\hline & slight & -1 \\
\hline \multirow{2}{*}{$\begin{array}{l}\text { al dynamics are limited or there is not a good balance } \\
\text { on. This can be an effect of actions in functional }\end{array}$} & remarkable & -2 \\
\hline & slight & -1 \\
\hline
\end{tabular}


the IHG index, the river course to be evaluated must be divided longitudinally in reaches. These river reaches should differ according to hydrogeomorphological criteria, such as discharge, valley slope, valley confinement and channel morphology.

The previous version of IHG has been improved in several respects. The updated version includes some improvements in the assessments of sediment supply and mobility and of riparian quality. The assessment of sediment supply and mobility now includes an evaluation of the impact of gravel and sand extractions and dredging. Moreover, the score and calculation of the longitudinal continuity of the riparian corridor have been changed by increasing the score discount for different types of ruptures. The riparian quality assessment has been reorganised to enhance the importance of the riparian corridor width, which has now been included as an independent second parameter within the riparian quality assessment. Additionally, the structure and naturalness and cross-sectional connectivity have been combined to form the third parameter within the riparian quality assessment.

\section{Functional quality assessment of the fluvial system}

The functional quality of the fluvial system is evaluated by adding the assessments of the following three parameters (Table 2):

a) Flow regime naturalness. This parameter is assessed in relation to the natural state. This standard of comparison implies that the river currently has a natural discharge regime with seasonal flow changes and floods.

b) Sediment supply and mobility. This parameter is assessed by examining how dams, dredging and extractions alter and reduce sediment flows. Importance is also given to the lateral inputs of sediment through mass failure processes and the contribution of tributaries.

c) Floodplain functionality. This parameter is assessed by considering how the presence of human activities in a floodplain could seriously modify its functionality.

\section{Assessment of the channel quality}

The channel quality assessment is obtained from the sum of the scores for the following parameters (Table 3):

a) Channel morphology and planform naturalness. Changes in the channel planform are evaluated by considering whether they are direct (channel realignment) or indirect (regulation, deforestation) human alterations.

b) Riverbed continuity and naturalness of the longitudinal and vertical processes. This parameter is estimated by considering the impact from dams and weirs (barrier effect, breaking longitudinal continuity, triggering incision processes downstream), and also from other types of human alterations in channels (dredging, gravel extractions, floorings, and vegetation clearcutting).

c) Riverbank naturalness and lateral mobility. This parameter considers pressures that confine the lateral mobility of the channel or alter the erosion and sedimentation processes (especially bank defences).

\section{Assessment of the riparian corridor quality}

The riparian corridor is the space (vegetated or not) in which the movement of the channel has occurred historically. In this section, the hydrogeomorphological function of the riparian corridor is assessed (Table 4) through the following key features:

a) Longitudinal continuity. This parameter is assessed according to the number of discontinuities in the riparian corridor resulting from human occupancy.

b) Riparian corridor width. The current width is assessed relative to the optimal width in the past or in a reference scenario.

c) Structure, naturalness and cross-sectional connectivity of the riparian corridor. Riparian patches and the internal quality of the riparian zone are estimated by evaluating disturbances and ruptures in the connectivity of the corridor. 
Table 4. Assessment of the riparian quality. Valoración de la calidad de las riberas.

Longitudinal continuity

\begin{tabular}{|c|c|c|c|}
\hline $\begin{array}{l}\text { The riparian corridor is continuous along the whole functional reach and } \\
\text { geomorphological conditions allow it }\end{array}$ & 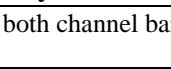 & & 10 \\
\hline $\begin{array}{l}\text { There are segments with non-recoverable or permanent land uses } \\
\text { (urbanization, factories, farms, gravel pits, stable linear infrastructures, } \\
\text { bridges, defences, ditches...) that break the longitudinal continuity of the } \\
\text { riparian corridor. There are surfaces with recoverable or non-permanent } \\
\text { land uses (poplar plantation, crops, logging, paths...) that mean } \\
\text { discontinuities }\end{array}$ & $\begin{array}{l}\text { if more than } \\
70 \% \text { of the } \\
\text { discontinuities } \\
\text { are permanent }\end{array}$ & $\begin{array}{c}\text { if } 30 \% \text { to } 70 \% \text { of } \\
\text { the discontinuities } \\
\text { are permanent }\end{array}$ & $\begin{array}{c}\text { if less than } 30 \% \text { of } \\
\text { the discontinuities } \\
\text { are permanent }\end{array}$ \\
\hline if riparian zone is entirely removed & -10 & -10 & -10 \\
\hline $\begin{array}{l}\text { If the length of the discontinuities are more than } 85 \% \text { of the } \\
\text { riverbank's length }\end{array}$ & -10 & -9 & -8 \\
\hline $\begin{array}{l}\text { If the length of the discontinuities are between } 75 \% \text { and } 85 \% \text { of the } \\
\text { riverbank's length }\end{array}$ & -9 & -8 & -7 \\
\hline $\begin{array}{l}\text { If the length of the discontinuities are between } 65 \% \text { and } 75 \% \text { of the } \\
\text { riverbank's length }\end{array}$ & -8 & -7 & -6 \\
\hline $\begin{array}{l}\text { If the length of the discontinuities are between } 55 \% \text { and } 65 \% \text { of the } \\
\text { riverbank's length }\end{array}$ & -7 & -6 & -5 \\
\hline $\begin{array}{l}\text { If the length of the discontinuities are between } 45 \% \text { and } 55 \% \text { of the } \\
\text { riverbank's length }\end{array}$ & -6 & -5 & -4 \\
\hline $\begin{array}{l}\text { If the length of the discontinuities are between } 35 \% \text { and } 45 \% \text { of the } \\
\text { riverbank's length }\end{array}$ & -5 & -4 & -3 \\
\hline $\begin{array}{l}\text { If the length of the discontinuities are between } 25 \% \text { and } 35 \% \text { of the } \\
\text { riverbank's length }\end{array}$ & -4 & -3 & -2 \\
\hline $\begin{array}{l}\text { If the length of the discontinuities are between } 15 \% \text { and } 25 \% \text { of the } \\
\text { riverbank's length }\end{array}$ & -3 & -2 & -1 \\
\hline If the length of the discontinuities are less than $15 \%$ & -2 & -1 & -1 \\
\hline
\end{tabular}

Riparian corridor width $\square$

The surviving riparian corridor keep all their potential width, so that they play perfectly their role in the hydrogeomorphological
system

\section{Structure, naturalness and cross-sectional connectivity of the riparian corridor $\square$}

In the surviving riparian corridor the natural stages of vegetation, the complexity of the habitats, the naturalness of the species, and all the transversal diversity is maintained, not existing any internal human obstacle that separates or disconnects the different habitats or environments

There are human pressures in the riparian zone (grazing, clearing of vegetation, logging, fires, aquifer exploitation, dead wood picking, oxbow lake filling, garbage, builder's rubble, recreational use...), that cause alterations in its structure; or that cause the riparian zone to became scrubland due to the disconnection of water table (incised channels)

if the alterations are very important

if the alterations are slight

The naturalness of the riparian vegetation has been altered by alien

species or plantations

The reach is laterally constricted, generally longitudinally or diagonally, by linear structures such as roads, defences, ditches, trails, paths. These structures alter the transversal connectivity of the riparian corridor

\begin{tabular}{|c|c|c|}
$\begin{array}{c}\text { if they extend more } \\
\text { than 50\% ofthe } \\
\text { current riparian } \\
\text { corridor }\end{array}$ & $\begin{array}{c}\text { if they extend } \\
\text { between } 25 \% \text { and } \\
50 \% \text { of the current } \\
\text { riparian corridor }\end{array}$ \\
\hline-4 & -3 & -2 \\
\hline-3 & if the & \\
\hline if the alterations are significant & \\
\hline if the alterations are slight
\end{tabular}

f they extend less than $25 \%$ of the current riparian corridor

\begin{tabular}{|l|c|c|}
\hline \multicolumn{1}{|l}{ length } & -10 & After applying these scores, if the final \\
if the Longitudinal continuity has resulted 0 (totally eliminated riparian corridor) & -2 & result is negative, assess 0
\end{tabular}

if the discontinuities are distributed throughout the whole sector and the addition of their lengths exceeds $150 \%$ of the reachlength

if the addition of the lengths of the discontinuities gives a value between $100 \%$ and $150 \%$ of the reach length

if the addition of the lengths of the discontinuities gives a value between $50 \%$ and $100 \%$ of the reach length $-2$ 10 


\section{ACKNOWLEDGEMENTS}

We wish to thank Francisco Martínez Capel (Universidad Politécnica de Valencia) and José Barquín (Universidad de Cantabria) for their comments and suggestions, and for inviting us to the meeting Physical Assessment Methods in Rivers, where this method was explained.

\section{REFERENCES}

ACÍN, V., D. GRANADO \& A. OLLERO. 2009. Caracterización y evaluación geomorfológica del río Bullaque. (Technical Report). Ciudad Real: Universidad de Castilla-La Mancha y Confederación Hidrográfica del Guadiana. 284 pp. + annexes.

ÁLVAREZ-CABRÍA, M., J. BARQUÍN \& J. A. JUANES, 2010. Spatial and seasonal variability of macroinvertebrate metrics: Do macroinvertebrate communities track river health? Ecological Indicators, 10(2): 370-379.

BALLARÍN, D. \& D. MORA. 2010. Asistencia técnica para la aplicación del índice hidrogeomorfológico (IHG) en la cuenca del Ebro (Technical Report). Zaragoza: Confederación Hidrográfica del Ebro. 360 pp. + annexes.

DÍAZ, E. \& A. IBISATE. 2009. Evaluación hidrogeomorfológica (IHG). In: Efectos de las minicentrales hidroeléctricas en los sistemas fluviales de los ríos Aragón y Arga (tramos medio y bajo): diagnóstico, tendencias y propuestas de gestión. C. Jaso y A. Ollero (dirs.): 305-329. Pamplona: Gestión Ambiental Viveros y Repoblaciones de Navarra.

GIMENO, M. 2009. El río Frasno. Caracterización hidromorfológica y análisis de riesgo de inundación. (Technical Report). Universidad de Zaragoza, $89 \mathrm{pp}$.
GONZALO, L. E. 2009. Dinámica fluvial y calidad hidrogeomorfológica de los ríos Ebro y Gállego en el entorno de Zaragoza. (Technical Report). Universidad de Zaragoza, 153 pp.

MALAVOI, J. R. \& J. P. BRAVARD. 2010. Éléments d'hydromorphologie fluviale. Vincennes: Office National de l'Eau et des Milieux Aquatiques (ONEMA), $224 \mathrm{pp}$.

OLLERO, A., D. BALLARÍN, E. DÍAZ, D. MORA, M. SÁNCHEZ FABRE, V. ACÍN, M. T. ECHEVERRÍA, D. GRANADO, A. IBISATE, L. SÁNCHEZ GIL \& N. SÁNCHEZ GIL. 2007. Un índice hidrogeomorfológico (IHG) para la evaluación del estado ecológico de sistemas fluviales. Geographicalia, 52: 113-141.

OLLERO, A., D. BALLARÍN, E. DÍAZ, D. MORA, M. SÁNCHEZ FABRE, V. ACÍN, M. T. ECHEVERRÍA, D. GRANADO, A. IBISATE, L. SÁNCHEZ GIL \& N. SÁNCHEZ GIL. 2008. IHG: un índice para la valoración hidrogeomorfológica de sistemas fluviales. Limnetica, 27(1): 171-188.

OLLERO, A., D. BALLARÍN \& D. MORA. 2009. Aplicación del índice hidrogeomorfológico IHG en la cuenca del Ebro. Guía metodológica. Zaragoza: Confederación Hidrográfica del Ebro, 93 pp.

RAVEN, P. J., N. T .H. HOLMES, I. P. VAUGHAN, F. H. DAWSON \& P. SCARLETT, 2010. Benchmarking habitat quality: observations using River Habitat Survey on near-natural streams and rivers in northern and western Europe. Aquatic Conservation: Marine and Freshwater Ecosystems, 20: S13-S30.

RINALDI, M., N. SURIAN, F. COMITI \& M. BUSSETTINI, 2010. Manuale tecnico-operativo per la valutazione ed il monitoraggio dello stato morfologico dei corsi d'acqua. Roma: Istituto Superiore per la Protezione e la Ricerca Ambientale, $191 \mathrm{pp}$. 
